Dirk Krausmüller

Mardin Artuklu University dkrausmuller@hotmail.com

\title{
HIDING IN PLAIN SIGHT: HETERODOX TRINITARIAN SPECULATION IN THE WRITINGS OF NIKETAS STETHATOS
}

When one looks for evidence of subversion in Byzantine religious literature, one will naturally first turn to the writings of known heretics and the refutations of these writings by their Orthodox opponents. However, such an approach fails to take into account authors who expressed heretical views in their works and were nevertheless never excluded from the Orthodox community. In this article I argue that the eleventh-century Stoudite monk Niketas Stethatos was one such figure: a member of the Constantinopolitan ecclesiastical establishment who nevertheless developed an understanding of the Trinity that deviated radically from official doctrine.

In order to make my case I focus on Niketas' speculations about a particular understanding of the divine image in the human being, the so-called Imago Trinitatis, where counterparts for the divine persons and their interrelations are sought in the human soul and its various faculties. In his three exposés of the Imago Trinitatis Niketas seems to follow the lead of earlier theologians who create straightforward links between the human mind, word and "spirit," on the one hand, and the divine Father, Son and Spirit, on the other, and who emphasise these links by referring to the Father and the Son as "Mind" and "Word." However, close analysis of his statements reveals that this impression is misleading and that Niketas creates instead three asymmetrical links, matching the divine Mind with the human "spirit," which he identifies with the soul, and further correlating the divine Word with the human mind, and the divine Spirit with the human word. As a consequence of this slippage the relation of "begetting" is not attributed to the human counterparts of the Father and the Son but rather to the human counterparts of the Son and the Spirit, which throws into question the validity of the analogy. 
In order to make sense of this evidence I consider two possible explanations, that Niketas wished to demonstrate to his readers the ultimate futility of facile analogies between God and creation that are based on simple homonymy; or that he intended the human image of soul, mind and word to be the blueprint for a reconfiguration of the divine archetype. Through analysis of a definition of the soul, which at first sight does not seem to be related to the topic of the Imago Trinitatis, I make the case that the latter explanation is correct. In this definition terms denoting the inner-Trinitarian relationships are applied to the soul and its faculties in a highly idiosyncratic manner. The mind as part of the soul has only one product, the word, and the relationship between these two entities is described not only as a "begetting" but also as an "emitting," a term that in orthodox theology denoted the relationship of the Father as the divine Mind with his second product, the Holy Spririt. On the strength of this evidence I argue that Niketas wished his readers to reorganise the traditional Trinity in such a way that a first hypostasis, the divine nature, begets a second hypostasis and this second hypostasis then in turn begets a third hypostasis. In a further step I show that this alternative model is already set out in exposés of the Imago Trinitatis by Symeon the New Theologian and that Niketas inserts himself into an existing tradition. In the last part of the article I ask how Niketas could nevertheless take on the role of a defender of traditional orthodox doctrine, and why he was never condemned for his heterodox teachings.

$* * *$

Niketas Stethatos entered the monastery of Stoudios in the early eleventh century when he was still a boy and returned there after an extended period of exile in order to take up the lifestyle of a hesychast and to act as the spiritual guide of a group of disciples. ${ }^{1}$ Other evidence shows that he eventually became abbot of Stoudios and that he died at an advanced age some years before the end of the eleventh century. ${ }^{2}$

(1) See Niketas Stethatos, Life of Symeon, 128-135, in Un grand mystique byzantin. Vie de Syméon le Nouveau Théologien (949-1022) par Nicétas Stéthatos. Text grec inédit, ed. by I. Hausherr (OrChr, 12), Rome, 1928, pp. 184-198.

(2) D. Krausmüller, “Private vs Communal: Niketas Stethatos's Hypotyposis for Stoudios, and Patterns of Worship in Eleventh-century Byzantine Monasteries," in Work and Worship at the Theotokos Evergetis, ed. by M. Mullett and A. Kirby (BBTT, 6.2), Belfast, 1997, pp. 309-328. 
From the remnants of his once extensive correspondence we can infer that Niketas played an important role in the religious and intellectual life of the capital. ${ }^{3}$ Today, however, he is best known as the champion of the mystic Symeon the New Theologian. Although he had hardly known Symeon during his life-time, Niketas was so impressed by him that he set out to establish his saintly status by organising a public cult and popularised his teachings by creating an annotated edition of his scattered oeuvre. ${ }^{4}$ One reason for Niketas' attraction to Symeon was without doubt Symeon's claim that those who possessed the Holy Spirit could speak authoritatively about all matters, both secular and religious. This claim gave Niketas the justification not only to express his views on how to achieve spiritual perfection but also to chide emperors for immoral conduct, to accuse philosophers of propounding heretical ideas, and above all to hold forth on doctrinal issues in defiance of the canonical stipulation that such teaching was reserved to the bishops. As is well known, he was one of the spokesmen of the Eastern Church in the discussions of the year 1054 when he attacked the Latin Church not only for its use of unleavened communion bread, but also for its erroneous views about the procession of the Holy Spirit. ${ }^{5}$

A survey of Niketas' extant literary production shows that his interest in the Trinity was not limited to his anti-Latin polemic but also

(3) See J. Darrouzìs, Nicétas Stéthatos. Opuscules et lettres (SC, 81), Paris, 1961, pp. 56-62, 228-290, 464-484; and also B. Markesinis, "Un extrait d'une lettre de Nicétas Stéthatos à Philothée l'Higoumène," in La spiritualité de l'univers byzantin dans le verbe et l'image. Hommages offerts à E. Voordeckers, ed. by K. Demoen and J. Vereecken (Instrumenta patristica, 30), Turnhout, 1997, pp. 173-192.

(4) See J. Koder, “Die Hymnen Symeons, des neuen Theologen. Untersuchungen zur Textgeschichte und zur Edition des Niketas Stethatos," Jahrbuch der Österreichischen Byzantinistik, 15 (1966), pp. 153-199.

(5) For a more detailed discussion of Niketas' role within the religious discourse of the capital, see my forthcoming article "Establishing Authority in the Constantinopolitan Religious Discourse of the Eleventh Century: Inspiration and Learning in the Writings of the Monk Nicetas Stethatos," in Charismatic Authority, Spiritual Friendship. Comparative Approaches to Networks of Learning, Byzantine East and 'Latin' West, c. 1000 - c. 1200, ed. by S. STECKEL and N. Gaul (International Workshop, Central European University, May 30/31, 2008). 
found expression in his treatise Against the Jews ${ }^{6}$ his Gnostic Chapters, ${ }^{7}$ and his contemplation On the Soul, ${ }^{8}$ which belong to different periods of his life. ${ }^{9}$ In these texts he develops his views on the divinity in the context of discussions of the Imago Trinitatis.

$* * *$

I start my analysis with the treatise Against the Jews since it contains the most elaborate exposé of the Imago Trinitatis within Niketas' oeuvre. In this treatise, whose date can unfortunately no longer be established with any certainty, Niketas defends the Christian belief that God can beget a son. He avers that God does not bring forth his Son in the same way as human fathers produce their offspring and then proceeds to support this claim through reference to the human being as the divine image in creation:

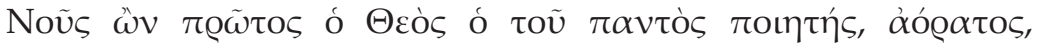

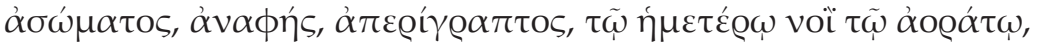

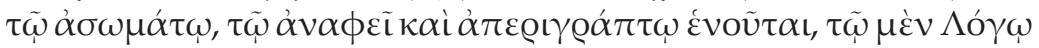

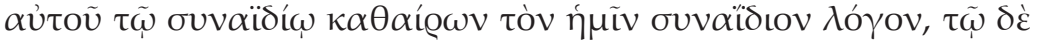

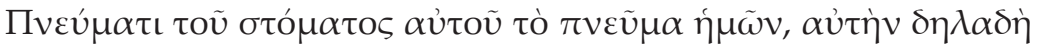

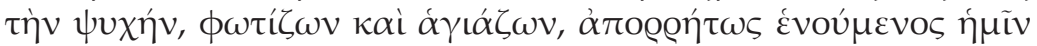

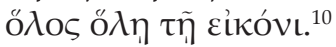

Being the first Mind, which is invisible, incorporeal, untouchable, uncircumscribable, God, the maker of the universe, is united with our mind, which is invisible, incorporeal, untouchable and uncircumscribable, cleansing through his co-eternal Word the word that is co-eternal with us, and illuminating and sanctifying through the Spirit of his mouth our spirit, that is, the soul itself, being ineffably united in his entirety with the entire image.

In this passage Niketas sets out the relationship between God and the human being by creating links between three components of the

(6) Niketas Stethatos, Against the Jews, ed. by Darrouzìs, Opuscules, pp. $412-442$.

(7) Niketas Stethatos, Gnostic Chapters, PG 120, 952-1009.

(8) Niketas Stethatos, On the Soul, in Opuscules, ed. by Darrouzès, pp. 64-152.

(9) For a discussion of the relative dates, see Opuscules, ed. by Darrouzès, p. 22.

(10) Niketas Stethatos, Against the Jews, 8, in Opuscules, ed. by Darrouzìs, pp. $420-422.1-7$. 
Trinity and three features within the human being, which are denoted by the same terms: mind, word and spirit. This framework would have been familiar to contemporary audiences because it had a long history, which stretched back to Christianity's formative years. ${ }^{11}$ Already in the Gospel of John the Son of God is referred to as Word of God in analogy to human beings who are endowed with articulated speech. This configuration was then expanded in Late Antiquity in two successive steps. Firstly, the divine Father came to be called mind in analogy to the human mind as the source of articulated speech; and secondly, the divine Spirit was also given a homonymous human counterpart. The fully developed framework appears in many theological texts from the final years of Late Antiquity and from the Byzantine period: a concise example can be found in Maximus' Ambigua, which contains the phrase "as having assimilated ...our mind and word and spirit to the great Mind and Word and Spirit" ( $\omega \varsigma$ voï

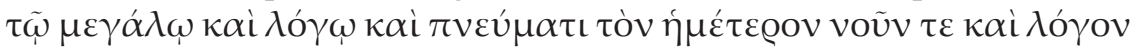
$\kappa \alpha i \pi v \varepsilon \tilde{v} \mu \alpha$... be no doubt that each of the three divine persons is linked to its homonymous counterpart. Thus one might conclude that this is also the intended meaning of Niketas' statement, in particular since there the links between the identical terms are further reinforced through the marked symmetry of the syntax. However, the following passage reveals that matters are not as straightforward:

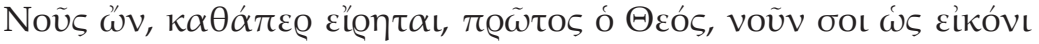

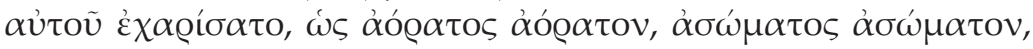

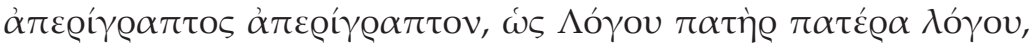

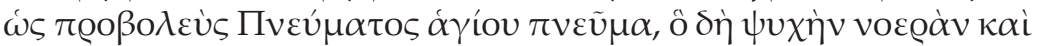

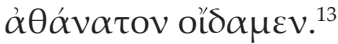

Being the first Mind, as has been said, God has given you as his image a mind. Being an invisible, incorporeal and uncircumscribable [Mind, God has given you as his image a mind that is]

(11) See L. Thunberg, Microcosm and Mediator: the Theological Anthropology of Maximus the Confessor (Acta Seminarii Neotestamentici Upsaliensis, 25), Lund, 1965, pp. 137-139; and my article "From Homoousion to Homohypostaton: Patriarch Methodius of Constantinople and Post-Patristic Trinitarian Theology," Journal of Late Antique Religion and Culture, 3 (2009), pp. 1-20, esp. p. 4.

(12) Maximus, Ambigua, 7 (PG 91, 1088A).

(13) Niketas Stethatos, Against the Jews, 9, in Opuscules, ed. by Darrouzìs, p. 422.1-5. 
invisible, incorporeal and uncircumscribable. [Being] a father of a Word, [he has given you as his image] a father of a word. Being an emitter of the Holy Spirit, [he has given you as his image] a spirit, which we know to be an intellectual and immortal soul.

In this passage the purpose of the human analogy reveals itself: God does not beget his Son in the way that human bodies produce offspring but rather in the way that human thought produces human speech. This point is made in the central statement where Niketas avers that the divine Mind as the "father" of the divine Word has a counterpart in the human mind as the "father" of the human word. However, as in the previous passage Niketas does not focus exclusively on the relationship between these two entities but adds another statement about the Mind as the emitter of the divine Spirit, which he then also complements with a human counterpart. At first it seems that Niketas has created a neat parallel between the two statements. However, a clos-

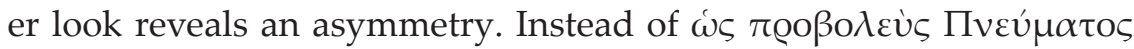
$\alpha \gamma$ '́ov $\pi \varrho \circ \beta \circ \lambda \varepsilon \dot{\alpha} \pi v \varepsilon \dot{u} \mu \alpha \tau o \varsigma$, which would have mirrored the pattern

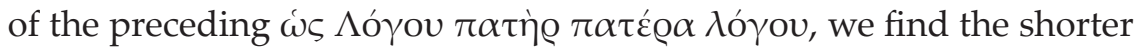

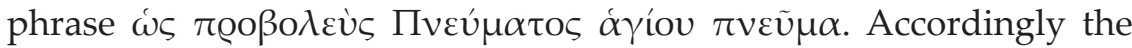
human spirit is correlated not with the divine Spirit itself but with the emitter of this Spirit. Since traditional Trinitarian theology requires that the emitter of the Holy Spirit is at the same time the father of the Word we seem to end up with a scenario where the divine Father corresponds to the human spirit and where the third person of the Trinity, the Holy Spirit, has no human counterpart at all. Since such a framework is clearly unsatisfactory one might at this point be tempted to conclude that the asymmetry is due to a lapse of the author or of the first copyist of the manuscript and that the text must therefore be

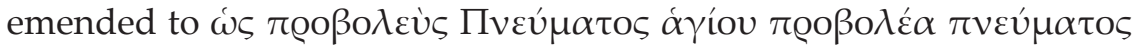
in order to perfect the overall symmetry of the sentence. However, this explanation runs into difficulties when we extend the analysis to the next sentence in Niketas' treatise:

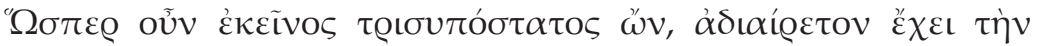

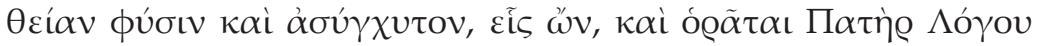

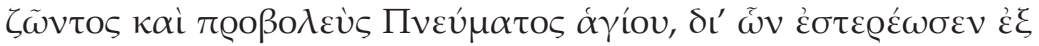

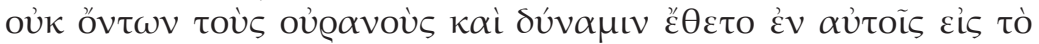

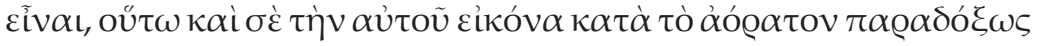

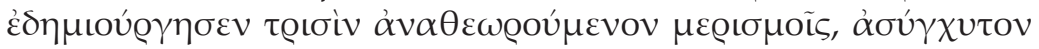

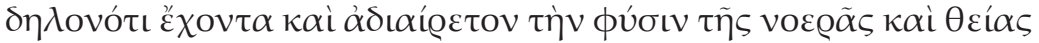

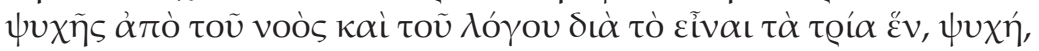




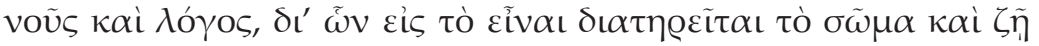

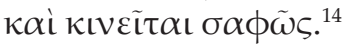

Just as He, who is tri-hypostatic, has the divine nature as [something that is] indivisible and distinct, for $\mathrm{He}$ is one, and is seen as Father of a living Word and emitter of a Holy Spirit, through Whom He has made the heavens firm out of nothing and has instilled in them the power of being, so He has also paradoxically created you - his image as far as [your] invisible part is concerned [in such a manner that you are] perceived as being tri-partite, since you obviously have the nature of the intelligible and divine soul as [something that is] distinct and indivisible from the mind and the word, because the three things - soul, mind and word - are one; through them the body is evidently preserved in its existence, lives and moves.

In this passage Niketas avers that both God and the human soul are one nature and at the same time three hypostases or parts. In order to demonstrate the correctness of his view he makes two complementary statements. Firstly, God and the soul are one because the divine nature cannot be separated from its Son and Spirit, just as the nature of the soul cannot be separated from its mind and word. Secondly, God and the soul are three because the divine nature is distinct from its Son and its Spirit, just as the soul is distinct from its mind and its word. From this argument it is evident that God and the soul are at the same time the common nature and one of the three hypostases or parts. This conflation of the hypostasis of the divine Father with the divine substance, though running counter to Cappadocian teaching, is not uncommon in Byzantine theological texts. ${ }^{15}$ However, in Nicetas' model of the Imago Trinitatis it leads to startling results. Contrary to our expectations the human word is not correlated with its homonym, the divine Word, but rather with the Holy Spirit.

$\begin{array}{llll}\text { Divine Archetype } & \Leftrightarrow & \text { Human Image } \\ \text { Father (nature) } & \Leftrightarrow & \text { soul (nature) } \\ \text { Word (Son) } & \Leftrightarrow & \text { mind } \\ \text { Holy Spirit } & \Leftrightarrow & \text { word }\end{array}$

(14) Niketas Stethatos, Against the Jews, 9, in Opuscules, ed. by Darrouzìs, p. 422.5-15.

(15) Cf. e.g. Pseudo-Athanasius, Quaestiones aliae (PG 28, 780B13-C3). 
And the discrepancy between the human and divine spheres becomes even more marked when we consider that in the previous passage the divine Father is referred to as "Mind" and the human soul is called "spirit." When we add these two elements we arrive at the following pattern.

$\begin{array}{ll}\text { Divine Archetype } & \Leftrightarrow \text { Human Image } \\ \text { Mind } & \Leftrightarrow \text { spirit } \\ \text { Word } & \Leftrightarrow \text { mind } \\ \text { Spirit } & \Leftrightarrow \text { word }\end{array}$

It is evident that this understanding of the divine image in the human being has consequences for the interpretation of the previous passage. First of all, it helps us to understand why the human spirit is not correlated with the divine Spirit but rather with the emitter of the divine Spirit: since the soul is a nature and therefore a primary entity it cannot be meaningfully equated with the Holy Spirit, which is a derivative entity, but only with its source, the divine Mind, who is assimilated to the divine nature. Accordingly we can conclude that the apparent asymmetry is required by Niketas' conceptual framework. Indeed, attentive readers could already have come to such a conclusion before they reach this point of Niketas' argument: as we have seen, the human "spirit" has from the very beginning been equated with the soul.

This shift forces us to reconsider the other seemingly straightforward symmetries in the previous passages. When Niketas states that

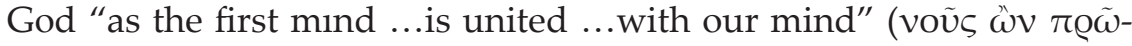

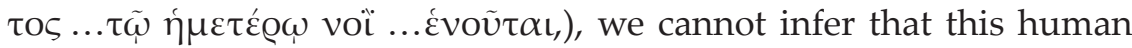
mind is the counterpart of the divine Mind within the framework of the divine image: as we have just seen, it corresponds instead to the divine Word. And the same correction is necessary for the statement that God "as a father of a Word ...bestows .... a father of a word"

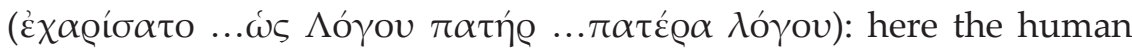
word must be regarded as the image not of the divine Word but of the divine Spirit. Accordingly, we do have a human counterpart for the divine Spirit in the previous sentence, which at first seemed to be missing. However, this counterpart not only appears in the "wrong" place but also within the "wrong" set of interrelations: in the human image the counterpart of the Word now seems to give birth to the counterpart of the Spirit, which calls into question the validity of the image relationship between God and the human being. 


$\begin{array}{ll}\text { Divine Archetype } & \Leftrightarrow \text { Human Image } \\ \text { Mind } & \Leftrightarrow \text { spirit } \\ \text { (is father of) } & \Leftrightarrow \text { mind } \\ \text { Word } & \Leftrightarrow \text { (is father of) } \\ \text { Spirit } & \Leftrightarrow \text { word }\end{array}$

It is evident that Niketas has gone to extraordinary lengths to produce this outcome. He has created a set of seemingly straightforward correspondences, which unravel as soon as one inspects his argument more closely. Before we can address the implications of this strategy we need to broaden the evidence base through analysis of an exposé of the Imago Trinitatis in Niketas' Gnostic Chapters.

$* * *$

Niketas' Gnostic Chapters, together with the Practical Chapters and the Physical Chapters that precede them, are the most comprehensive discussion of his spirituality. Three series of one hundred short statements explain to monastic audiences what the three stages of spiritual ascent are and how one can progress from one stage to the next. ${ }^{16}$ Since "theology" is considered to be the culmination of this process it is not surprising that the Gnostic Chapters start with a cluster of statements about the divinity and its components. In these statements the Imago Trinitatis plays a central role. Niketas gradually introduces individual elements of the analogy before setting out the full framework in chapter six:

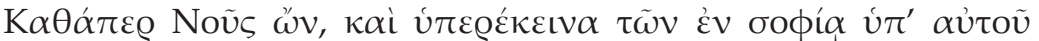

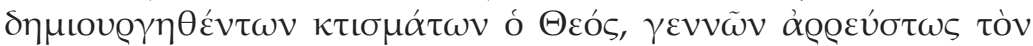

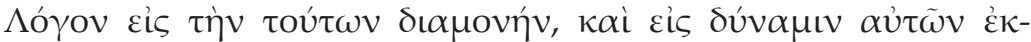

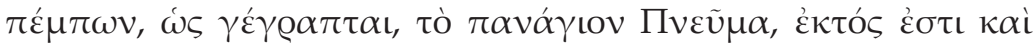

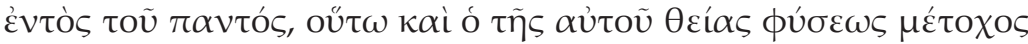

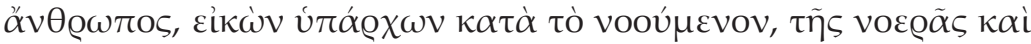

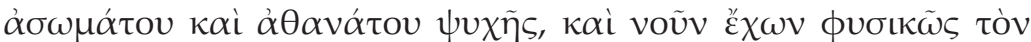

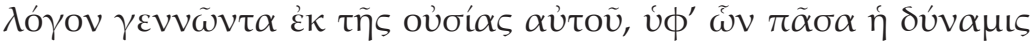

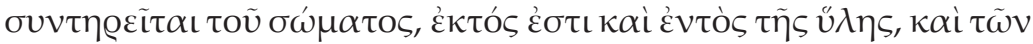

(16) Niketas Stethatos, Practical Chapters, Physical Chapters, Gnostic Chapters (PG 120, 851-1010). On this literary genre see E. von IvánKA, "Kephalaia. Eine Byzantinische Literaturform und ihre antiken Wurzeln," BZ, 47 (1954), pp. 285-291. 


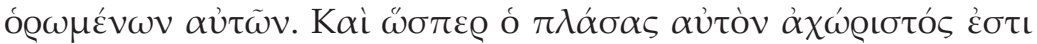

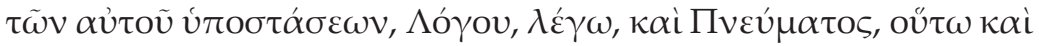

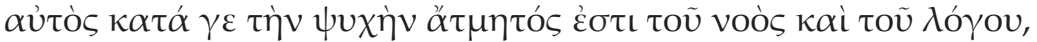

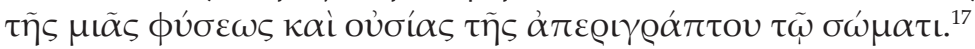

Just as God who is Mind and transcends the creatures made by Him in his wisdom, and who begets without change the Word for their preservation, and who dispatches, as has been written, the all-holy Spirit for their empowerment is outside and inside the universe, so is the human being inside and outside of matter and the visible things, [the human being] who is partaker of His divine nature, being His image in the intelligible sphere on account of the intelligible and incorporeal and immortal soul, and having a mind that begets the word naturally out of His substance; by these things all power of the body is preserved. And just as his Creator is inseparable from His hypostases, I mean, Word and Spirit, so also is he himself inseparable in his soul from the mind and the word, the one nature and substance which is not circumscribed by the body.

As in his treatise Against the Jews, Niketas ostensibly has recourse to the human image in order to make a point about the divine archetype. He argues that the soul is not confined to the body, which it animates, and that the same must therefore be true for God and the whole of creation. Within this framework the nature of the image relationship is then further elaborated. The reader's attention will first be drawn to the strik-

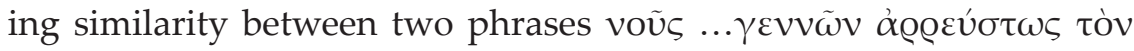

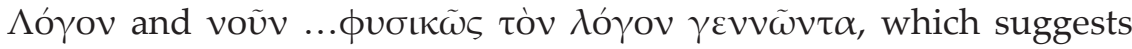
that the two statements are directly linked to each other. However, a look at the context reveals an asymmetry: whereas God is said to be a Mind, the human soul as its counterpart is introduced as having a mind, and there is no human counterpart at all for the Holy Spirit. The second comparison provides us with the key for resolving this discrepancy. There we are told that God relates to the Word and the Spirit as the soul relates to the mind and the word. This statement reflects the same non-Cappadocian Trinitarian model that we have already encountered in the treatise Against the Jews. By denoting Word and Spirit as the Father's hypostases Niketas indicates that he wishes the Father to be identified with the divine nature.

Divine Archetype: Creator (nature) $\Rightarrow$ Word + Spirit (hypostases)
Human Image: soul (nature) $\Rightarrow$ mind + word (faculties)

(17) Niketas Stethatos, Gnostic Chapters, 6 (PG 120, 956C2-D3). 
Although the term "Mind" is not used in the second comparison the reader will supply this missing information and thus come to the conclusion that the two relationships of "begetting" mentioned in the first comparison are asymmetrical: the human counterpart of the divine Word "begets" the human counterpart of divine Spirit.

$\begin{array}{ll}\text { Divine Archetype } & \Leftrightarrow \text { Human Image } \\ \begin{array}{l}\text { Mind (Creator) } \\ \text { (begets) }\end{array} & \Leftrightarrow \text { soul } \\ \text { Word } & \Leftrightarrow \text { mind } \\ & \text { (begets) } \\ \text { Spirit } & \Leftrightarrow \text { word }\end{array}$

This is, of course, the same configuration that we have already encountered in the treatise Against the Jews. Thus we can conclude that Niketas' model of the divine image is remarkably consistent. The main characteristic of this model is the mismatch between the divine and human spheres. Like many earlier Late Antique and Byzantine theologians who engaged in speculation about the Imago Trinitatis, Niketas uses the same terms mind, word and spirit to denote the three persons of the Trinity and their counterparts in the human being, but contrary to tradition he does not correlate the homonyms with each other but instead creates three asymmetrical relationships by linking the divine Mind to the human "spirit," which he identifies with the soul, and by further correlating the divine Word with the human mind, and the divine Spirit with the human word. As a consequence the relationship of "begetting" does not link the human counterparts of the divine Father and Son but instead the human counterparts of the divine Son and Spirit.

However, these asymmetries are not always obvious. Indeed, one can argue that Niketas creates deliberately misleading statements. In his Gnostic Chapters he twice uses the same formula "a mind begetting a word" and thus gives the impression that this relation links the same entities at the human and divine levels. The correct understanding reveals itself only when one combines information from two consecutive comparisons. In the treatise Against the Jews we find even more extreme cases of obfuscation. Here Niketas starts with three consecutive statements that seem to link the homonymous terms mind, word and spirit; and in the next paragraph he inserts an apparent mistake, the single word "spirit" instead of the full phrase "emitter of a spirit," into a series of parallelisms and thus tempts his readers to perfect the overall symmetry by "correcting" this mistake, with the effect that they will then have missed a vital clue to his real intentions. 
$* * *$

Our findings so far raise two questions. Firstly, why did Niketas create such flagrant mismatches between the divine archetype and the human image? Secondly, why did he take steps to hide his interpretation of the Imago Trinitatis from his readers? As far as I can see, there are only two possible explanations: either he wished to demonstrate to his readers the ultimate futility of facile analogies between God and creation that are based on simple homonymy; or he intended the human image to be the blueprint for a reconfiguration of the divine archetype. In the former scenario the strategies of concealment would have a primarily pedagogical function: the ideal reader would experience the breakdown of superficial coherence and would thus learn that the divine mystery cannot be comprehended in such a simplistic manner. The latter scenario suggests a different explanation, namely that Niketas chose to disguise his interpretation of the Imago Trinitatis, because he did not wish to be branded as a heretic.

Since Niketas was a member of the ecclesiastical establishment and was even allowed to defend the Orthodox position in the controversies of 1054, one might be tempted to conclude that only the former interpretation can be correct. However, then one would need to admit that Niketas does not present a very effective argument. If he had wished to show that the human analogy cannot adequately reflect the being of God, one would have expected him to jumble up the correlations between the divine and human components in a random manner. Instead he always reproduces the same model where the human image is in itself entirely coherent even if it does not match with the divine archetype.

Thus we must consider the possibility that this human image is indeed the model for an alternative Trinity. This raises the question: can we find evidence that would allow us to substantiate such a hypothesis? When we look at the passages that we have discussed so far we can see that Niketas uses his strategies of concealment quite selectively. When he juxtaposes the divine Mind with its Word and Spirit and the human soul with its mind and word he usually does so quite openly. By contrast, he always attempts to conceal the true meaning of passages in which the relationship of begetting is mentioned. In order to explain this discrepancy one can point out that the two scenarios have quite different implications. In the former case the asymmetry could be explained as a mere terminological discrepancy since the orthodox teaching that one hypostasis, the Father, is the cause of two further 
hypostases, the Son and the Spirit, seems reflected at the human level as well. Such an explanation is not possible in the latter case since here "begetting" links the first and the second entity at the divine level and the second and third entity at the human level. Thus one could argue that Niketas focuses his efforts at concealment specifically on the most problematic aspects of his model.

$* * *$

It is evident that these observations alone do not suffice to show that Niketas intended to reconfigure the traditional Trinity. However, a passage in Niketas' late treatise On the Soul may allow us to come to a more definite conclusion. This passage starts with another exposé of the Imago Trinitatis:

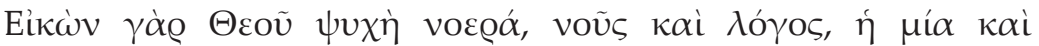

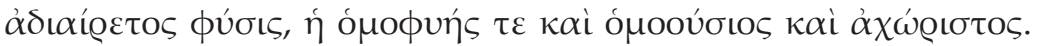

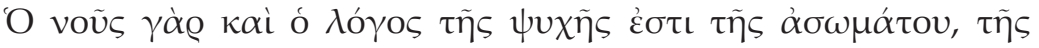

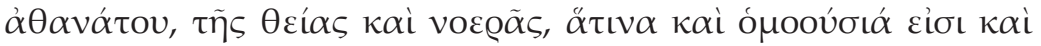

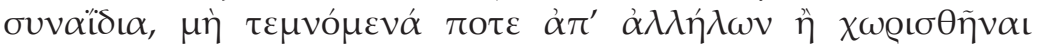

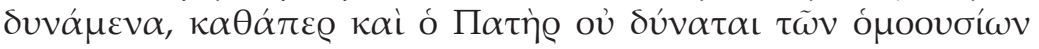

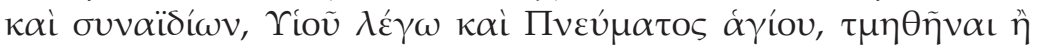

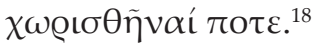

For the image of God is the intellectual soul, the mind and the word, the one indivisible nature, of the same nature and of the same substance and inseparable. For the mind and the word belong to the incorporeal, immortal, divine and intellectual soul, and these are of the same substance and of equal eternity and can never be cut off or separated from each other, just as the Father, too, can never be cut off or separated from those of the same substance and of equal eternity, I mean, the Son and the Holy Spirit.

As before the three divine persons Father, Son and Spirit are correlated with the human soul, mind and word. In this case the discrepancy is less obvious because Niketas does not refer to the Father and the Son as the divine Mind and Word but such identification can without doubt be assumed. In addition we note the absence of references to the relationships between the different entities. However, this does not mean that Niketas has omitted this aspect as becomes obvious when we turn to the immediately following passage:

(18) Niketas Stethatos, On the Soul, 22, in Opuscules, ed. by Darrouzìs, p. 84.1-8. 


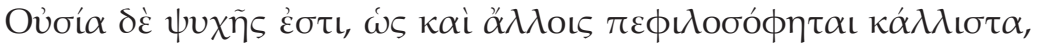

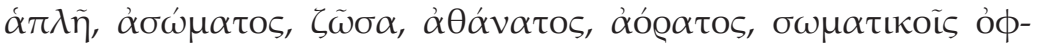

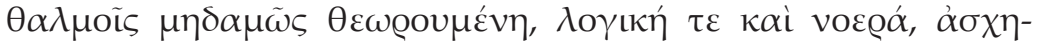

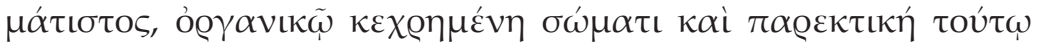

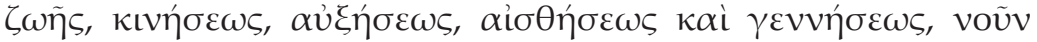

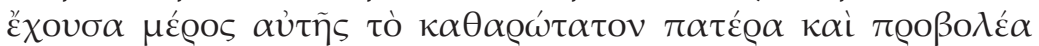

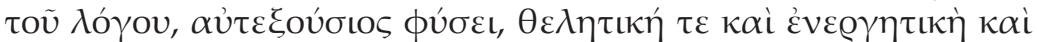

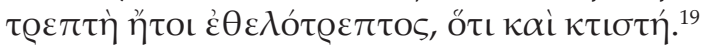

The substance of the soul, as has also been discussed exceedingly well by others, is simple, living, immortal, invisible, in no way seen by corporal eyes, articulate and intellectual, shapeless, using the body as a tool and providing it with life, movement, growth, sense perception and generation, having a mind as its purest part, father and emitter of a word, naturally free, endowed with will and activity and changeable or changing according to will because it is also created.

Ostensibly this passage is not another statement about the Imago Trinitatis but a definition of the soul. However, a closer look reveals that it contains several features, which link it to other discussions about the divine image in the human being. Not only do we find the three elements "soul," "mind" and "word" but the relationship between the human mind and the human word is expressed through the terms "father" ( $\pi \alpha \tau \eta \dot{ } \varrho)$ and "emitter" ( the relationships between God and his Son and between God and his Spirit. Thus one can argue that this passage complements the previous exposé of the Imago Trinitatis by supplying the elements that were missing there. At this point one might object that the passage is not relevant to the topic because the divine archetype is not made explicit. However, here we need to be aware that Late Antique and Byzantine authors often set out incomplete versions of the Imago Trinitatis, where only the human dimension is presented. In these cases the configuration of the soul serves as "proof" for the correctness of Trinitarian doctrine. In order to lead their readers to the right conclusions the authors describe the relationships between the different parts of the soul with terms that have been transposed from the divine level. ${ }^{20}$ Anastasios of

(19) Niketas Stethatos, On the Soul, 24, in Opuscules, ed. by Darrouzès, p. 86.1-9.

(20) See, for example, Gregory of Nazianzos, Twenty-Ninth Oration, 9, in Grégoire de Nazianze, Discours 27-31 (Discours théologiques), ed. and trans. by P. Gallay (SC, 250), Paris, 1978, p. 180.14-17. 
Antioch, for example, states that "we call the mind the father of the

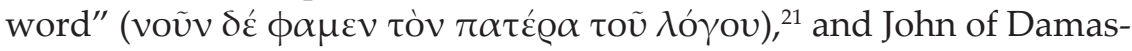
cus explains that human beings are in the image of God "insofar as

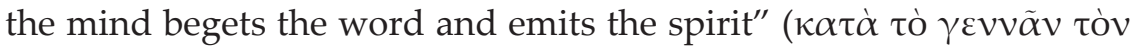

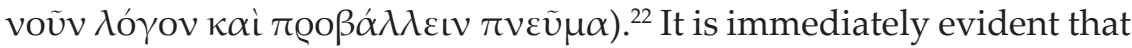
such phrases bear a striking resemblance to Niketas' definition of the "substance ...of the soul" (oúrí $\alpha . \psi \psi v \chi \tilde{\eta} \varsigma$ ) as "having a mind as its

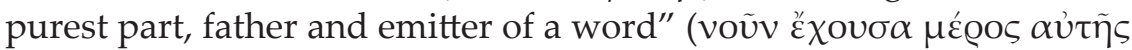

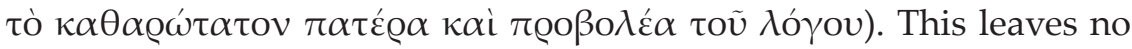
doubt that like Anastasios and John, Niketas wished his readers to supply the missing divine archetype. However, if we take this step we arrive at startlingly different results. Whereas the exposés of the earlier authors reinforce the orthodox position that God begets the Word and emits the Holy Spirit, Niketas' version suggests a divinity where the relationship between God and his Word is defined as a begetting and as an emitting and where there is therefore no room left for the Holy Spirit as the traditional third hypostasis.

$\begin{array}{ll}\text { Human Image } & \Leftrightarrow \text { [Inferred Divine Archetype] } \\ \text { mind (begetter and emitter) } & \Leftrightarrow \text { [Mind / "Father" / "Emitter"] } \\ \text { word (offspring and emission) } & \Leftrightarrow \text { [Word / "Son" / "Spirit"] }\end{array}$

However, Niketas also took steps to conceal the relevance of the passage for the Imago Trinitatis. We have already seen that at first sight it appears to be a definition of the soul. This definition is found in the same chapter as the exposé of the Imago Trinitatis that I have quoted earlier. However, this chapter is preceded by the two-fold title "What is 'in the image and likeness of God' and what is the substance of the

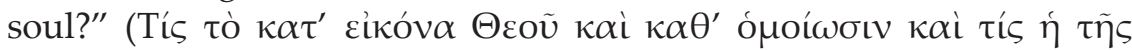
$\psi v \chi \tilde{\eta} \varsigma$ oúfí $\alpha){ }^{23}$ Thus the reader is given the impression that Niketas deals with two entirely different topics. Moreover, the reference to the mind and the word is part of a long list of qualifications of the soul,

(21) Anastasios of Antioch, First Dogmatic Exposition, 31, in Anastasii I Antiocheni opera omnia genuina quae supersunt, ed. by S. N. SАккоs, Thessaloniki, 1976, p. 26.22-24.

(22) John of Damascus, On the Two Wills in Christ, 30, in Die Schriften des Johannes von Damaskos IV. Liber de haeresibus. Opera polemica, hrsg. B. KоттеR (PTS, 22), Berlin, New York, 1981, S. 215-216.2-3.

(23) Niketas Stethatos, On the Soul, in Opuscules, ed. by Darrouzìs, p. 82, tit. According to the editor this title is no later addition but was already found in the archetype. 
which have no bearing on the theme of the Imago Trinitatis, so that its significance can be easily missed. And lastly the definition of the soul itself is borrowed from John of Damascus as Niketas indicates in the phrase "as has been discussed exceedingly well by others, too" ( $\omega \varsigma \kappa \alpha i$

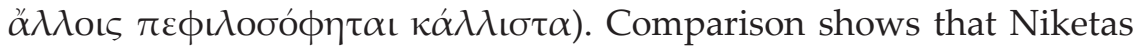
follows his model almost slavishly apart from the statement "having a mind as its purest part, father and emitter of the word" (voũv है $\chi 0 v \sigma \alpha$

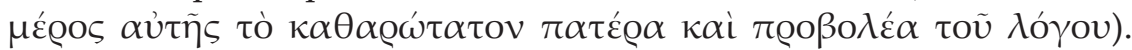
Here John of Damascus' text has instead the anti-Apollinarian formula "having the mind not as something else beside itself, but as its purest

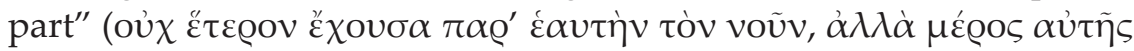

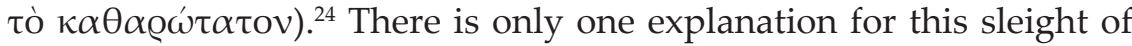
hand: Niketas wished to give the impression that his definition of the relationship between the mind and the word, too, was borrowed from John of Damascus and thus had the backing of this universally recognised church father.

It is evident that in this case Niketas' strategies of concealment cannot be explained as a pedagogical tool because they aim to hide the very fact that the passage might be related to the Imago Trinitatis. This confirms our previous interpretation that Niketas did indeed wish his readers to take the human image as the starting point for a reorganisation of the divine counterpart. At this point we need to ask: how do the results of our analysis of the definition of the soul relate to the exposés of the Imago Trinitatis in the treatise Against the Jews and in the Gnostic Chapters? As we have seen in these two texts Niketas consistently correlates the Trinity with the soul as a nature and the mind and its offspring, the word, as faculties. This suggests that in the definition of the soul, too, Niketas wishes his readers to regard the substance of the soul as part of the Imago Trinitatis. If we make the implied divine archetype explicit we arrive at the following scenario:

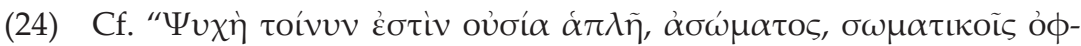

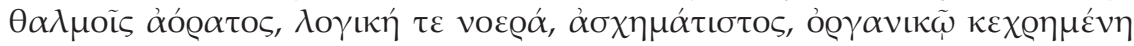

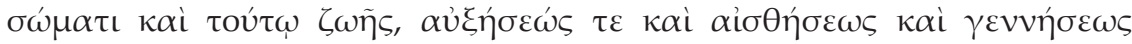

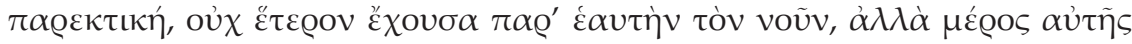

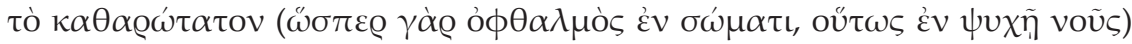

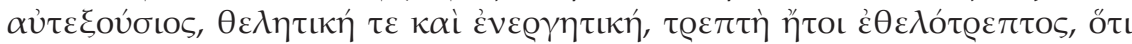

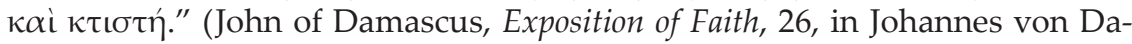
maskos, Die Schriften, II, hrsg. B. Kotтer (PTS, 12), Berlin, New York, 1973, S. 75.44-50). 


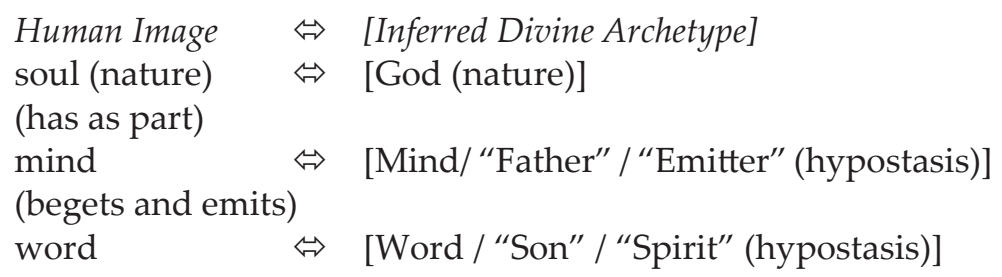

However, this does not mean that the three texts present identical configurations because in the treatise Against the Jews and in the Gnostic Chapters the relationship between mind and word is characterised exclusively through the term "begetting"; and the nature of the soul is called "spirit." This model, too, can be complemented with a divine archetype:

$\begin{array}{lll}\begin{array}{l}\text { Human Image } \\ \text { soul/spirit (nature) }\end{array} & \Leftrightarrow & \text { [Inferred Divine Archetype] } \\ \text { (has) } & \Leftrightarrow & \text { [Spirit (nature) } \\ \begin{array}{l}\text { mind } \\ \text { (begets) }\end{array} & \Leftrightarrow & \text { [Mind/Father (hypostasis)] } \\ \text { word } & \Leftrightarrow & {[\text { Word/Son (hypostasis)] }}\end{array}$

Thus it seems that in the treatise On the Soul the Spirit is amalgamated with the Word whereas in the treatise Against the Jews and in the Gnostic Chapters he is identified with the divine nature. However, this discrepancy is more apparent than real. It is evident that the term Spirit can only denote the divine nature after the suppression of the traditional third hypostasis, which proceeds from the Father. This, however, is exactly what we find in the definition of the soul in the treatise On the Soul where the relationship between the human mind and its word is characterised as both "begetting" and "emitting." As a consequence the traditional Holy Spirit is amalgamated with the Son and the name "spirit" is freed up for a different use.

The heretical character of this model is immediately evident: the Second Ecumenical Council had condemned the Pneumatomachoi who did not accept the doctrine that the Holy Spirit proceeds from the Father as a third hypostasis; ${ }^{25}$ and later synods had anathematised the Tetraditai who regarded the common divine nature as a separate fourth hypostasis beside the three hypostases of Father, Son and

(25) See M. A. G. Haykin, "And Who Is the Spirit? Basil of Caesarea's Letters to the Church at Tarsus," VC, 41 (1987), pp. 377-385. 
Spirit. ${ }^{26}$ There can be no doubt that Niketas was aware of this fact because in his model the two heresies cancel each other out: because the third hypostasis is suppressed the characterisation of the divine nature as a hypostasis of its own does not create a tetrad; and because the divine nature is called "spirit" he cannot be accused of being an enemy of the Spirit. As a consequence Niketas can preserve the traditional creedal formula of a Trinity of Father, Son and Spirit and thus give the impression of subscribing to orthodox doctrine.

So far we have established the divine archetype exclusively through making inferences from the human image. Now we need to ask: how does this reconfigured Trinity relate to Niketas' explicit statements about the divine archetype? In our previous discussion of the various exposés of the Imago Trinitatis we found the following recurring pattern.

$\begin{array}{lll}\text { Human Image } & \Leftrightarrow & \text { Explicit Divine Archetype } \\ \text { spirit (nature of the soul) } & \Leftrightarrow & \text { Mind-Father (divine nature) } \\ \text { mind-father } & \Leftrightarrow \text { Word-Son } \\ \text { word-son } & \Leftrightarrow \text { Spirit }\end{array}$

This juxtaposition results in an asymmetrical set of relationships. Readers who assume that Niketas is an orthodox thinker will conclude that the archetype is perfectly above board and will dismiss the terminological inconsistency at the human level as an irrelevant oddity. However, when one takes the human image as the starting-point one will come to the conclusion that for Niketas the terms Father, Son and Spirit do not have their traditional orthodox meanings but denote the divine nature, the Father and the Son instead.

It is evident that this interpretation does not solve all problems because we are still left with a mismatch between the inner-Trinitarian relations. In archetype and image the relationship of begetting appears in different places. As we have seen the soul has the mind as a part and the mind is in turn the father of the word. This configuration can be complemented with a matching Trinitarian counterpart where the divine nature has the Father as a part and where the Father in turn begets the Son. However, in Niketas' explicit statements about the Imago Trinitatis the name Father is applied to the divine nature and the name Son to the first hypostasis, with the consequence that their relationship is also characterised as a begetting:

(26) See below note 43 . 


$\begin{array}{ll}\begin{array}{l}\text { Explicit Divine Archetype } \\ \text { Mind }\end{array} & \Leftrightarrow \text { Divine Archetype Inferred from the } \\ \text { (begets) } & \Leftrightarrow \text { Divman Image } \\ \text { Word } & \Leftrightarrow \text { Mind } \\ \text { Spirit } & \Leftrightarrow \text { (begets) }\end{array}$

How are we to explain this discrepancy? I would argue that in this case we are not meant to reduce one configuration to the other but rather to conclude that the two scenarios are equally valid. Then we would arrive at a divinity where the divine nature as a first "father" produces a first "son" and where this first "son" then in turn becomes the "father" of a second "son."

If we accept this interpretation we are left with one last problem. Niketas states repeatedly that the Father begets the Son and emits the Spirit. In his framework the Father is, of course, not the traditional first hypostasis but rather the divine nature to which this hypostasis belongs. However, even so a scenario where one entity produces more than one other entity should not be possible in the Trinitarian model that we have reconstructed. Here Niketas' definition of the soul may give us a clue. As we have seen there the relationship between human mind and human word is characterised both as "begetting" and as "emitting." Thus one must consider the possibility that Niketas wishes his readers to conclude that the two statements "the Father begets the Son" and "the Father emits the Spirit" do not refer to two different relations but are rather two alternative ways of describing the same relation. The resulting framework can be presented as follows:

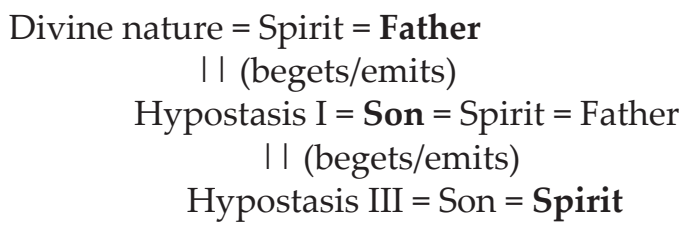

In this framework there is indeed a sequence of Father, Son and Spirit, which permits Niketas to give the impression that he is making orthodox statements. However, the terms Father, Son and Spirit are not firmly linked to one hypostasis only but appear at different levels. Hypostasis I is the Son of the divine nature but the father of hypostasis II and the term "spirit" is the common name of three components. 
This conclusion is the result of a complex argument. Thus one could object that the proposed "heretical" reading of Niketas' Trinitarian speculation is far-fetched and that Niketas simply got his terms wrong. Fortunately, however, Niketas was not the first Byzantine author who developed such an alternative Trinity. In a recent article I have sought to demonstrate that the writings of Symeon the New Theologian contain strikingly similar passages. ${ }^{27}$ In his forty-fourth hymn, which is devoted to the topic of the Imago Trinitatis ${ }^{28}$ Symeon identifies the human counterparts for the three divine persons as the nature of the soul and its two faculties mind and word, and thus reproduces the basic pattern that we have encountered time and again in Niketas' writings. ${ }^{29}$ However, there is an important difference between the approaches of the two authors. As we have seen Niketas never complements the human image with an exactly matching but heretical divine archetype. By contrast, Symeon sets out his ideas much more explicitly:

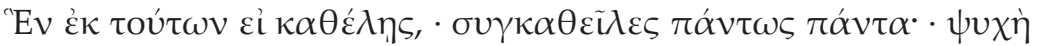

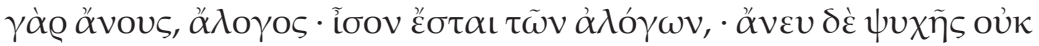

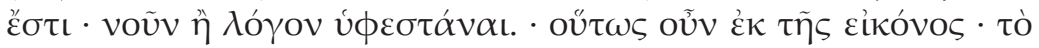

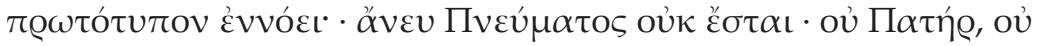

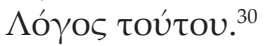

If you took away one of these, you would take away all of them altogether, because a soul without mind, without word is like that of the dumb beasts, whereas without a soul it is not possible for mind or word to subsist. Thus, then, infer the archetype from the image: without the Spirit there will be no Father, no Word of his.

In this passage Symeon argues that the soul cannot be separated from its properties and that the same must therefore be true for the divinity

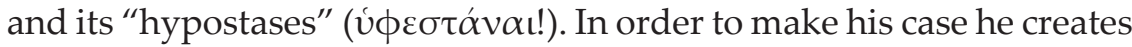
a strict parallel between the two spheres.

$\begin{array}{lll}\text { Human Image: soul } & \Leftrightarrow \text { mind + word } \\ \text { Divine Archetype: Spirit } & \Leftrightarrow \text { Father + Word }\end{array}$

(27) D. Krausmüller, "Reconfiguring the Trinity: Symeon the New Theologian, the 'Holy Spirit,' and the Imago Trinitatis," Byz, 81 (2011), pp. 212-236.

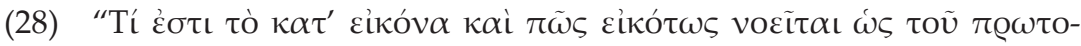

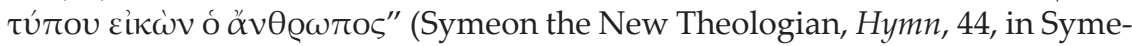
on le Nouveau Théologien, Hymnes, ed. by J. Koder, trans. by J. Paramelle and L. Neyrand, 3 vols. (SC, 156, 174, 196), Paris, 1969-1973, III, pp. 70-100).

(29) See ibid., pp. 72-74. 39-48.

(30) Ibid., p. 74.55-64. 
Thus we are presented with an alternative Trinity where the traditional third hypostasis, which has the Father as its cause, is suppressed and where the name Spirit denotes the common divine nature, which precedes both the divine Father and his sole offspring, the Word. This confirms our previous assumption that Niketas wished his readers to take the human image as the starting point for a reorganisation of the divine archetype.

However, this does not mean that Symeon does not also create "traditional" Trinitarian scenarios consisting of Father, Son and Spirit. In fact, in his Second Theological Oration he sets the two models alongside each other:

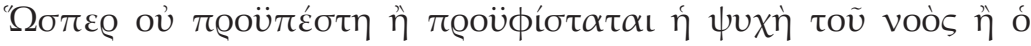

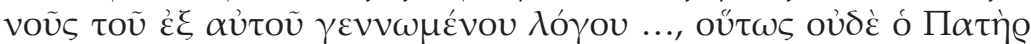

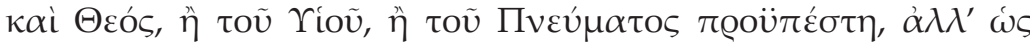

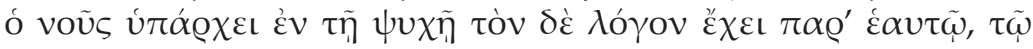

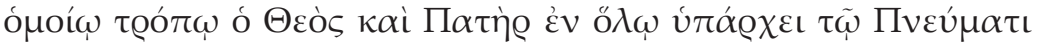

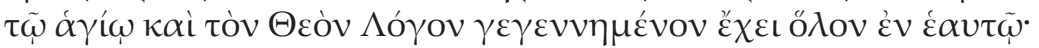

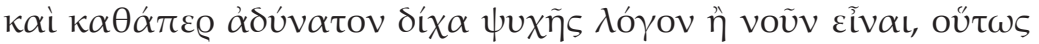

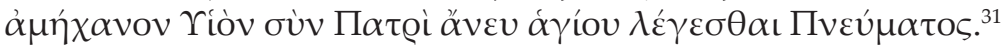

I for one, then, believe that, as the soul did not and does not pre-exist the mind or the mind the word that is born out of it, ... thus the Father, too, did not pre-exist either the Son or the Spirit, but as the mind is in the soul and has the word with it, in similar fashion the God and Father is in the entire Holy Spirit and has in itself the entire God Word, which has been begotten, and as it is impossible for the word or mind to be without the soul, thus is it impossible for the Son with the Father to be spoken of without the Spirit.

Here Symeon claims that as the soul does not pre-exist its faculties so does the first component in the Trinity not pre-exist the other two components. However, this first component is not always identified in the same way.

Father begets Son = Spirit

soul $=$ mind begets word

Spirit contains Father contains/begets Word soul contains mind contains word

(31) Symeon the New Theologian, First Theological Treatise, in Syméon le Nouveau Théologien, Traités théologiques et éthiques, ed. and trans. by J. DARRouzès, 2 vols. (SC, 122, 129), Paris, 1966-1967, I, pp. 136-138.96-106. 
It is evident that at the human level the configuration remains the same in both comparisons whereas in the divine counterpart the elements shift their positions. There is only one way in which one can make sense of this asymmetry. We need to assume that Symeon wishes to signal to his readers that the Trinitarian names are interchangeable and furthermore that the relationship of begetting links both the first and the second component and the second and the third component. Such a reading becomes possible because in the first comparison the relationship between Father and Spirit remains undefined.

There can be no doubt that Niketas' interpretation of the Imago Trinitatis is directly influenced by Symeon's Trinitarian speculation. His exposés can therefore be considered as variations of an existing theme. Niketas' original contribution is the invention of new strategies of concealment since the carefully crafted symmetrical statements in the treatise Against the Jews and in the Gnostic Chapters have no counterparts in Symeon's writings. This raises the question: how did Niketas become aware of Symeon's teachings? There is no indication that he was directly instructed by the great mystic. Indeed, Niketas tells us quite clearly that he hardly knew Symeon. Therefore we must conclude that he gained his knowledge from studying Symeon's texts with which he was intimately familiar through his editorial activity.

$* * *$

The discussion so far has shown that Niketas engaged in heretical Trinitarian speculation. This conclusion comes as a surprise because Niketas is not only known for his devotion to Symeon's spiritual legacy but also for his defence of official orthodox Trinitarian doctrine. He not only participated in the debates with the papal delegation in 1054 but also wrote a treatise, the so-called Synthesis, in which he attacked the Western teaching of the filioque. ${ }^{32}$ This treatise offers a whole arsenal of arguments in support of the Eastern position that God is the father of the Word and the only emitter of the Spirit. Indeed, it can be regarded as the foundational text of Byzantine anti-Latin polemic because it was extensively mined by later authors such as Nicholas of

(32) Niketas Stethatos, "Synthesis," in Humbert und Kerullarios. Quellen und Studien zum Schisma des XI. Jahrhunderts, ed. by A. Michel, 2 vols. (Quellen und Forschungen aus dem Gebiete der Geschichte, 21), Paderborn, 1924-1930, I, pp. 371-409. 
Methone. ${ }^{33}$ How can we explain this glaring discrepancy? One possible answer is that in 1054 he did not yet hold heretical views about the Trinity. However, this seems unlikely because by that time he was already intimately familiar with Symeon's writings. Thus one might conclude that Niketas deliberately set aside his own beliefs in order to assert the official Eastern position against the Westerners. Yet this might be too simplistic an answer. Here we need to remember that in his exposés of the Imago Trinitatis Niketas always gives the impression that he presents official doctrine and the heretical subtext only becomes obvious after intensive engagement with the texts. Thus one could argue that he used the same strategies of concealment in the Synthesis. In this case he would have to have constructed arguments that on the surface asserted the Orthodox position against Western innovation but when examined more closely reflected his own position. This may seem an almost impossible task but it should not be ruled out a priori that the text can indeed be read in this way.

A proper evaluation of Niketas' attitude towards official doctrine can only be attempted after careful analysis of the Synthesis. ${ }^{34}$ However, it is suggestive that in his discussions of the Imago Trinitatis he always preserves traditional creedal formulae such as the belief in a Trinity of Father, Son and Spirit, although he interprets these terms and their inter-relations in entirely untraditional ways. One reason for this approach is without doubt that he wished to conceal his real beliefs. However, one must also consider the possibility that he preserved such formulae because he regarded them as "orthodox." Indeed, it may be that he saw official doctrine and his own position as exoteric and esoteric interpretations of the same truth. In this case it would be wrong to regard Niketas' stance as duplicitous.

At this point we must ask: did the authorities ever become aware of Niketas' Trinitarian speculation and if so, how did they react to it? There can be no doubt that in 1054 Niketas was regarded as a good orthodox Christian because otherwise he would not have been allowed to enter into a debate with the papal legate Humbert of Silva Candida. Thus one could argue that members of the religious establishment

(33) The borrowings are identified in in the apparatus fontium of Michel's edition of the Synthesis.

(34) Niketas' arguments in the Synthesis are extraordinarily complex and often include elements that seem to be irrelevant for the point he is trying to make. In a future article I will attempt to show that these elements are pointers to an alternative reading. 
simply did not follow up Niketas' clues. Such an interpretation seems to find confirmation in an exchange of letters between Niketas and the patriarchal chartophylax Niketas of Koronis. From these letters we learn that Niketas sent his treatise On the Soul to the chartophylax and that the chartophylax responded to this gift with a number of sometimes petty queries, which suggests that he read the text quite carefully. ${ }^{35}$ Nevertheless, there is no indication that he was puzzled by the unconventional exposés of the Imago Trinitatis. Yet this evidence may be misleading because another patriarchal deacon, the didaskalos Niketas, wrote a dedicatory poem to Niketas' edition of Symeon's theological orations. In this poem it is stated that Symeon "was kindled ... in his soul, word and mind by the coal that has the force of three suns" ( $\phi \lambda \varepsilon \chi \theta \varepsilon i \varsigma .$.

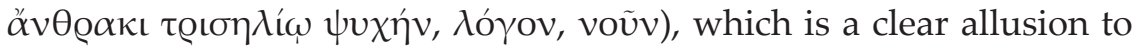
Symeon's version of the Imago Trinitatis. ${ }^{36}$ Thus one must consider the possibility that at least some members of the ecclesiastical establishment were "in the know." After all Niketas had learnt his heretical views from Symeon's writings, and there is no reason why other readers of Symeon should not have drawn the same conclusions.

This does not necessarily mean that Niketas never experienced difficulties. In our previous discussion we have seen that he is considerably more circumspect than Symeon. Whereas Symeon openly sets out an alternative Trinity of Spirit, Father and Son where Spirit denotes the divine nature, Niketas always keeps the traditional sequence of Father, Son and Spirit so that the reader is forced to establish the true meaning of these names exclusively by making inferences from the human image. One explanation for such caution can be found when we turn to his Confession of Faith, ${ }^{37}$ which he composed in "extreme ...

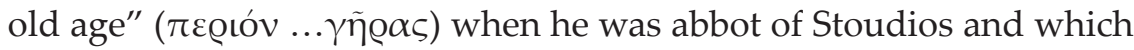
therefore most likely dates to the late 1070 s or $1080 \mathrm{~s} .{ }^{38}$ At the beginning of this text Niketas states that he was induced to make his beliefs

(35) Niketas Stethatos, Correspondence with Nicholas of Koronis, in Opuscules, ed. by DarrouzÈs, pp. 228-244. See esp. p. 242.1-8, with a query why Niketas has mentioned as characteristics of the body that it can flow or change, but not that it can be cut.

(36) Niketas Didaskalos, Dedicatory poem, in Traités, ed. by Darrouzìs, I, p. 90.16-17. On Nicetas and his functions, cf. Darrouzès' introduction in Traités, I, pp. 53-54.

(37) Niketas Stethatos, Confession of Faith, in Opuscules, ed. by DarrouzÈs, pp. $444-462$.

(38) For a discussion of the date, see Opuscules, ed. by Darrouzìs, p. 22. 
known to a wider public "because of the ones who inflict damage on arguments, who have learnt to be nosy and who strive to chase the expressions, if not to twist them, so as to endanger those who have begotten the words themselves from their guileless and straightforward

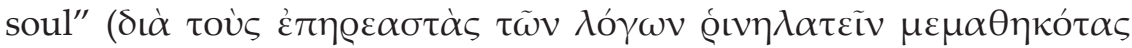

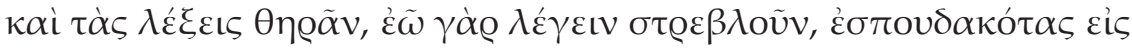

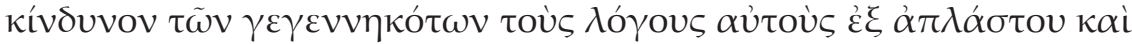
$\varepsilon \dot{v} \theta \varepsilon i ́ \alpha \varsigma \psi v \chi \tilde{\eta} \varsigma) .{ }^{39}$ The gist of this passage is clear: Niketas claims that that some of his readers mistakenly see a hidden meaning in perfectly straightforward and simple statements. There can be no doubt that he presents himself in his writings as an unsophisticated writer, but as we have seen a whole other dimension reveals itself to readers who follow up the various clues that he inserts into his arguments. Therefore one can hypothesise that Niketas' opponents read his texts in the way in which he intended them to be read - pondering on possible meanings of phrases and syntactical structures in order to discover the underlying alternative conceptual framework - but that they did so not in order to engage in the discourse on his own terms, but rather in order to attack him as a heretic.

Niketas does not explicitly state that his enemies attacked his Trinitarian beliefs. However, his statement that he has "begotten" his words can be understood as an allusion to the Imago Trinitatis. Significantly these words are said to emanate not from the mind as the highest faculty of the soul as one would expect from Niketas' other treatments of the topic but rather directly from the soul itself. It is evident that by eliding the mind Niketas removes the element responsible for the mismatch between archetype and image. As a consequence the nature of the soul as begetter of the word can be correlated with the divine nature, which becomes the Father of the divine Son and Word. This is an entirely orthodox use of the Imago Trinitatis, which can be found in the writings of older authorities such as Patriarch Photius. ${ }^{40}$

Unsurprisingly Trinitarian theology plays a prominent role in Niketas' Confession of Faith. We first encounter a definition of the Christian God as Father, Son and Spirit and an affirmation of the belief that the

(39) Niketas Stethatos, Confession of Faith, 2, in Opuscules, ed. by DarROUZÈs, p. 446.11-15.

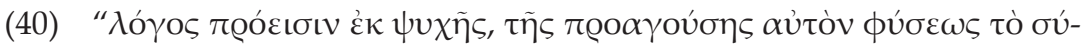

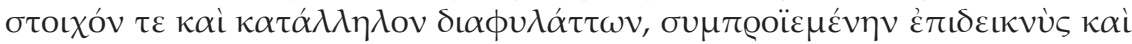

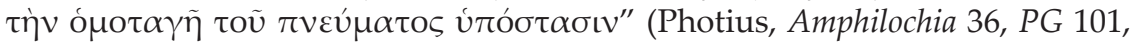
256A13-16). This statement is part of an exposé of the Imago Trinitatis. 
Son and the Spirit originate in the Father. In a second step we are then presented with a lengthy denunciation of alternative heretical interpretations. Given Niketas' earlier anti-Latin polemic one would expect him to focus on the procession of the Holy Spirit. However, to the surprise of the editor Darrouzès this is not the case. ${ }^{41}$ The only exception appears to be the parenthesis "and we do not recognise another prin-

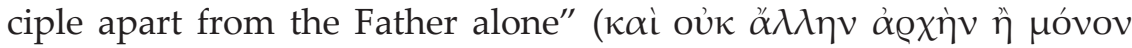
$\tau o ̀ v ~ \Pi \alpha \tau \varepsilon \dot{\rho} \alpha \gamma(v \omega \sigma \kappa о \mu \varepsilon v)$, which is inserted into the initial creedal statement, because it seems to be directed against the view that the Word is the principle of the Spirit. ${ }^{42}$ However, a closer look reveals that this parenthesis, together with the entire passage in which appears, is borrowed from a letter of Sophronios who was patriarch of Jerusalem in the seventh century. ${ }^{43}$ In his letter Sophronios was reacting against the heresy of the Tetraditai who introduced the common substance as a separate fourth component beside the three hypostases, which then became the principle of Father, Son and Spirit. ${ }^{44}$ There can be no doubt that Niketas, too, had the Tetraditai in mind because in the subsequent passage he refutes their position in greater detail. ${ }^{45}$ Thus one can argue that Niketas chose Sophronios' letter from a wide range of available models because he felt the need to distance himself from this heresy, which was embarrassingly close to his own position where the divine nature produces a further entity, which then becomes a father of a son.

However, this does not necessarily mean that Niketas was now wholeheartedly embracing the orthodox position. It is true that he characterises the Word as "born from the God and Father himself" ( $\dot{\varepsilon} \xi$

(41) Opuscules, ed. by Darrouzès, p. 447, note 4 .

(42) Ibid., p. 446.5-6.

(43) Sophronius of Jerusalem, Synodical Letter to Sergius of Constantinople,

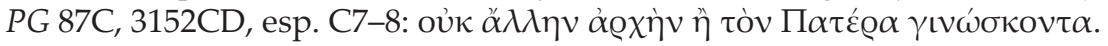

(44) See Timothy of Constantinople, On the Reception of Heretics into the Church, PG 86A, 60AC. For an unguarded "Tetradite" statement see Anasta-

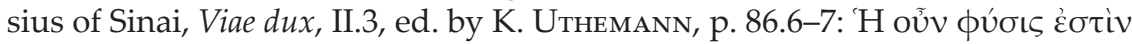

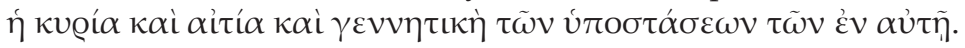

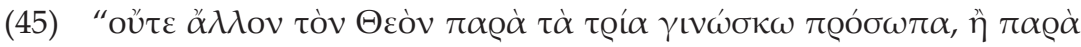

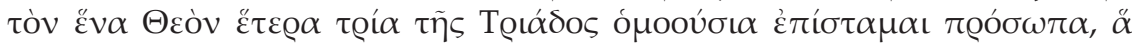

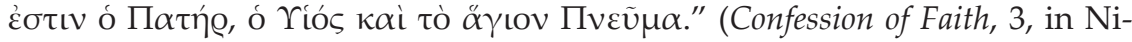
ketas Stethatos, Opuscules, ed. by Darrouzès, p. 448.10-13). In his previous discussions of the Imago Trinitatis Niketas had avoided this scenario by identifying the divine nature either with the Father, or with the Spirit. 


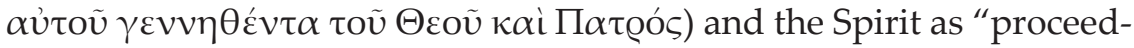

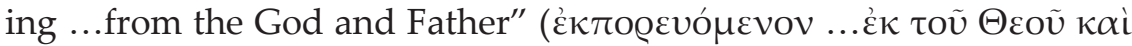

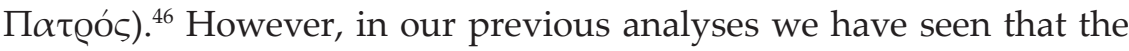
"father" of the Spirit is not necessarily identical with the "father" of the Word. Since Niketas does not explicitly identify the two "fathers" with one another it is possible to equate the "father" of the Word with the Spirit and thus to conclude that the "father" of the Spirit is the "grandfather" of the Word. Indeed, Niketas may have given us a hint by creating one of his cherished asymmetries. Having characterised the Word as "light from light and true God from true God" ( $\phi \tilde{\omega} \varsigma \dot{\varepsilon} \kappa$

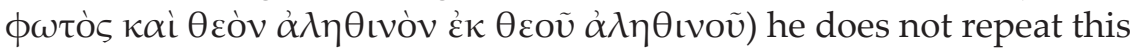
formula in the case of the Spirit but presents us with the shorter ver-

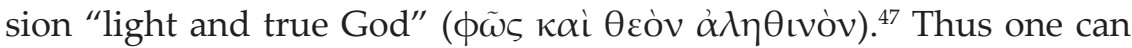
argue that the Spirit as "light and true God" is identical with the "light and true God" from which the Son emanates. It is evident that this interpretation does not constitute proof that Niketas persisted in his unconventional views. However, the fact that a "heretical" reading is possible should warn us not simply to assume that he had given in to the pressure of his adversaries.

Unfortunately Niketas does not identify the person or persons who forced him to defend his orthodoxy. However, a passage in his treatise On the Soul may give us a clue. There he attacks an unnamed philosopher who taught that the soul is inactive after its separation from the body and that prayers to alleviate the lot of the dead are therefore of no use to them. ${ }^{48}$ As Darrouzès and Guillard have argued this philosopher is most likely John Italos. ${ }^{49}$ Since Italos was later condemned by the church it would appear that in this debate Niketas had the backing of the ecclesiastical establishment. ${ }^{50}$ However, a closer look at the evidence reveals a more nuanced picture. In

(46) Niketas Stethatos, Confession of Faith, 3, in Opuscules, ed. by DARROUZÈs, p. 446.4-5,9.

(47) Ibid., p. 446.6-7,9-10.

(48) Niketas Stethatos, On the Soul, in Opuscules, ed. by Darrouzìs, p. 136, apparatus.

(49) See Darrouzìs, Opuscules, p. 21; and J. Gouillard, “Léthargie des âmes et culte des saints: un plaidoyer inédit de Jean diacre et maïstor," TM, 8 (1981), pp. 171-186.

(50) See J. Gouillard, "Le procès officiel de Jean l'Italien: les actes et leurs sous-entendus," TM, 9 (1985): pp. 133-169. 
a treatise addressed to Emperor Michael VII Italos criticises the notion that human souls can improve their condition after death. ${ }^{51}$ Such a notion was dangerously close to the outlawed Origenist teaching of universal salvation. Significantly, Niketas' Confession of Faith contains a section in which he first affirms his belief in an active afterlife of the soul and then immediately proclaims that the punishment in Hell is eternal and that Origen is a detestable heretic. ${ }^{52}$ Given the acrimonious relationship between the two men it can be argued that John Italos attacked Niketas not only for his views on the afterlife but also for his teachings about the Trinity. However, if Italos did indeed take such step it must have caused Niketas only minor discomfort. There is no evidence that he was ever forced to condemn his own works. Indeed, it is highly unlikely that such a step was ever taken because otherwise one would expect that the writings in which he sets out his Trinitarian speculation had been suppressed. This is all the more surprising as the late eleventh century was a period when the authorities were more concerned with heresy than ever before, and when unconventional thinkers such as the mystic Theodore of Blachernai incurred severe punishments. ${ }^{53}$

$* * *$

The evidence presented in this article shows that in the tenth and eleventh century highly respected members of the Byzantine religious establishment with apparently impeccable orthodox credentials could engage in a discourse about the Trinity that was utterly irreconcilable with official doctrine. Whereas official doctrine affirmed that the first person of the Trinity, the Father, begets the Son and emits the Spirit, and that the common divine nature should not be counted as a separate entity, Niketas Stethatos, and Symeon the New Theologian before

(51) John Italos, Quaestiones quodlibetales, ed. by P. JoAnnou (Studia Patristica et Byzantina, 4), Ettal, 1956, pp. 63-68. In the introduction Italos refers to contemporaries who pride themselves in their piety. This may well be a reference to Niketas Stethatos.

(52) Niketas Stethatos, Confession of Faith, 13, in Opuscules, ed. by DarROUŻ̀s, pp. 456-458.1-13.

(53) On Theodore of Blachernae, see J. Gouillard, "Quatre procès de mystiques à Byzance (vers 960-1143)," RÉB, 36 (1978), pp. 29-33, 57-67, esp. p. 52. On the changing intellectual climate in general, see esp. P. Magdalino, Manuel I Komnenos, 1143-1180, Cambridge, 1993, and P. Lemerle, Cinq études sur le XI ${ }^{e}$ siècle byzantin, Paris, 1977. 
him, constructed an alternative Trinity where the divine nature, now called Spirit, becomes the "father" of a "son" and where this "son" in turn becomes the "father" of another "son." This model is set out in exposés of the Imago Trinitatis where the human image, which is defined as a nature, the soul, with two faculties, the mind and the word, serves as a starting-point for a reorganisation of the divine archetype, which when considered in isolation seems to be entirely orthodox. While the result is always the same there are noticeable differences in the manner in which the two authors construct their texts. Compared with Symeon, Niketas shows a greater penchant for creating apparently symmetrical statements, which contain one deviation that then provides the key for a reinterpretation. The fact that Niketas adopted Symeon's conceptual framework raises the possibility that Symeon himself inherited this discourse from an earlier generation and that Niketas found followers in the twelfth century. ${ }^{54}$ Only further study will reveal if this is indeed the case. However, even the evidence presented so far raises questions about the Byzantine understanding of the concept of "orthodoxy." We will, of course, need to consider how Symeon and Niketas justified to themselves the fact that they were deviating from official doctrine. However, we will also need to ask what the ecclesiastical establishment thought about their Trinitarian speculation. In the previous discussion it has become apparent that attentive readers would have had little difficulty in discovering the true meaning of their writings. Thus we cannot argue that Symeon and Niketas escaped condemnation as heretics because their teachings remained hidden. Then, however, we are confronted with the question why the church would have tolerated an alternative Trinitarian model. Could it be that it was an integral part of the Byzantine élite discourse, and that the strategies of concealment were employed not to deceive the authorities but readers who were not members of the élite?

(54) For a possible precursor, cf. D. KRAUSMÜLLER, “From Homoousion to Homohypostaton: Patriarch Methodius of Constantinople and Post-Patristic Trinitarian Theology," Journal of Late Antique Religion and Culture, 3 (2009), pp. 1-20. 


\section{SUMMARY}

This article makes the case that Niketas Stethatos, and Symeon the New Theologian before him, constructed an alternative Trinity where the divine nature, now called Spirit, becomes the "father" of a "son" and where this "son" in turn becomes the "father" of another "son." This model is set out in exposés of the Imago Trinitatis where the human image, which is defined as a nature, the soul, with two faculties, the mind and its offspring, the word, serves as a starting-point for a reorganisation of the divine archetype, which when considered in isolation seems to be entirely orthodox. 